\title{
Performance analysis of an air conditioner with variable thermostat and ambient temperature
}

\author{
Bashab Jyoti Phukan ${ }^{1}$, Dr.S.K.Deb ${ }^{2}$ \\ Assistant Professor, Assam Engineering College, Guwahati, India ${ }^{1}$ \\ Professor, Assam Engineering College, Guwahati, India ${ }^{2}$
}

\begin{abstract}
Air conditioners are used for maintaining a good Thermal Comfort (TC) and Indoor Air Quality (IAQ) inside the air conditioned room. Performance of air conditioner generally reflects the TC, IAQ inside the room and the power consumption by the air conditioner. In this study a Split Air Conditioner (SAC) of 1.5 ton (TR) is considered for experimentation. This study investigates how the power consumptions vary with the variation of thermostat temperature and ambient temperature. It is found that in the environment of Guwahati it is not necessary to keep the thermostat temperature always below $20^{\circ} \mathrm{C}$ to maintain the thermal comfort. This investigation shows that a good amount of power and money can be shaved by controlling the Thermostat Temperature (TT) with respect to Ambient Temperature (AT). The finding indicates that at a constant ambient temperature of $32^{0} \mathrm{C}$ when the thermostat temperature set at $18^{\circ} \mathrm{C}, 22^{\circ} \mathrm{C}$ and $24^{\circ} \mathrm{C}, 21 \%$ and $35 \%$ of power can be shaved in case of $22^{\circ} \mathrm{C}$ and $24^{\circ} \mathrm{C}$ in comparison to $18^{0} \mathrm{C}$. This paper further indicates that at constant thermostat temperature of $19^{0} \mathrm{C}$ when the ambient temperature varies like $21^{\circ} \mathrm{C}, 24^{\circ} \mathrm{C}$ and $28^{\circ} \mathrm{C}, 15 \%$ and $41 \%$ power reduction occurs in case of $24^{\circ} \mathrm{C}$ and $21^{\circ} \mathrm{C}$ in comparison to $28^{0} \mathrm{C}$.
\end{abstract}

Keywords: TC, IAQ, SAC, TR, TT, AT

\section{INTRODUCTION}

Air conditioners are now days considered as one of the essential commodity which can maintain a good thermal comfort and indoor air quality. Performance of air conditioner is a great concern of today's life as $40 \%$ of the electricity is consumed by the buildings due to the air conditioners. Lot of power consumption is always threat to the society. As the uses of air conditioner are growing exponentially the power consumption growth rate is also increasing tremendously. For the increasing of global temperature the use of air conditioner is also increasing. Therefore the reduction of energy consumption in building is one of the way to reduce green house emission. The power consumed by an air conditioner can be minimized by efficient controlling of thermostat temperature. It also depends on the ambient weather temperature how the energy efficiency of the air conditioner will vary.

In 2014, QUANG T N,HE Cong-rong, KNIBBS L D,DEAR R D[1], had done an experimental investigation on cooptimisation of indoor environmental quality and energy consumption within urban office buildings.

In 2009, A Avgelis and AM Papadopoulos[2], discusses a study which aims to develop a method for choosing and managing in the best possible way Heating, Ventilating and Air Conditioning (HVAC) systems in new and existing buildings.This method utilizes a combination of two analysis tools, the multi-criteria decision making and building simulation towards the direction of a holistic assessment of a holistic assessment of HVAC systems. In 2016, Shailendra Singh Chauhan and S.P.S. Rajput [3], carried out experimental analysis of an vapour compression based combined air conditioning system for providing required human comfort conditions at comparatively low cost. They have experimentally analysed the combined system in an experimental setup at Bhopal, India. They found that the designed air conditioning system provides required human comfort condition from both temperature and humidity point of view and works well for around eight months in a year. In 2002, I P Knight and G N Dunn[4], presented a 3-year field monitoring programme researching the energy consumption of air conditioning systems in UK offices. Preliminary findings of the work indicates that laboratory system efficiency tests are not sufficient to predict whether one AC system will be more efficient than another when installed in a real building. The work suggests instead that the primary factors affecting A/C system energy performance "as installed" are system design, system control and the loads served by the system. In 2007, Ruey Lung Hwang and Ming Jen Chung[5], conducted field experiments in 29 airconditioned offices, used survey questionnaire and physical measurements to investigate, workers subjective thermal responses and comfort perception. In 2013, Nan Wang, Jiangfeng Zhang and Xiaohua Xia[6] made an analysis on energy consumption calculation model of a data center in South Africa which is presented to estimate the energy consumption of air conditioners at different temperature set points. They found that coefficient of variation of root mean square error between the estimated data and measured test data is $11.5 \%$. 


\section{International Advanced Research Journal in Science, Engineering and Technology}

Vol. 6, Issue 2, February 2019

In 2016, Xin Zhou, Da Yan and Xing Shi[7] focuses a study on three actual engineering projects of residential communities where centralized AC systems are adopted. This study shows that in residential buildings, at the point where the centralized feature of the system meets the decentralized feature of users' load, the problems of high energy consumption and low energy efficiency could easily occur.

In 2013, Brahim Mebarki, Belkacem Draoui, Boumediene Allaou and Lakhdar Rahmani[8] made an analysis to stimulate the air conditioning system impact on the power energy source of an electric vehicle powered by a lithiumion battery.

In 2007, B.F Yu, Z.B Hu,M.Liu,H.L Yang and Y.H Liu[9] made an study on air-conditioning systems and indoor air quality control for healthy indoor environment.In this paper recent research is reviewed on air-conditioning system and indoor air quality control for indoor air quality control for healthy indoor air environment.

In 2016, Kwesi Mensah and Jong Min Choi[10] made an analysis to for reducing the energy consumption significantly according to increment of setting temperature of the chamber as well as ensuring system stability for temperature and humidity chambers

\section{EXPERIMENTAL SETUP AND PROCEDURE}

In this experiment a 1.5 ton split air conditioner is considered for the experimentation as shown in Figure.1. Here in this experiment two cases were considered. For case I at the fixed ambient temperature the power consumed by the air conditioner was measured when the thermostat temperature was set at different temperature for duration of one hour each. For case II the power consumed by air conditioner was measured when the thermostat temperature is kept fixed for different ambient temperature. The instrument used for the experimentation was hygrometer, clamp meter and thermocouple as shown in figure 2,3 and 4 .

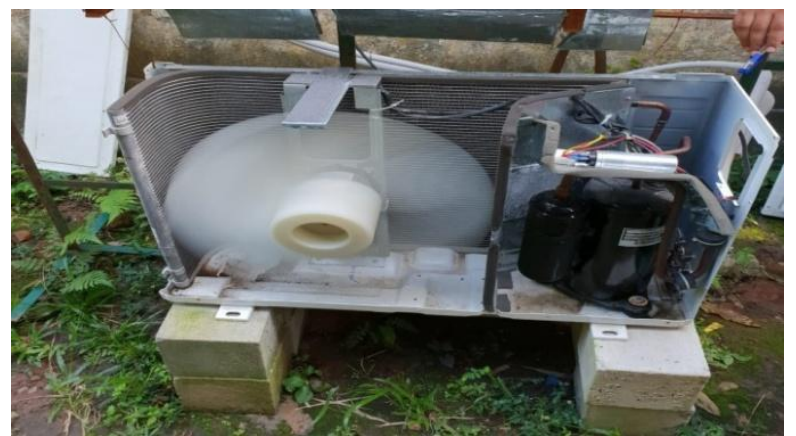

Figure1. Experimental set up

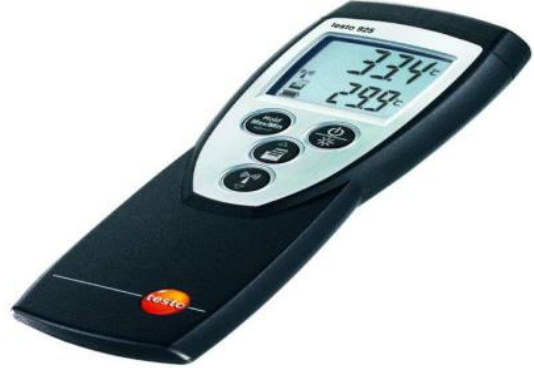

Figure2.Hygrometer

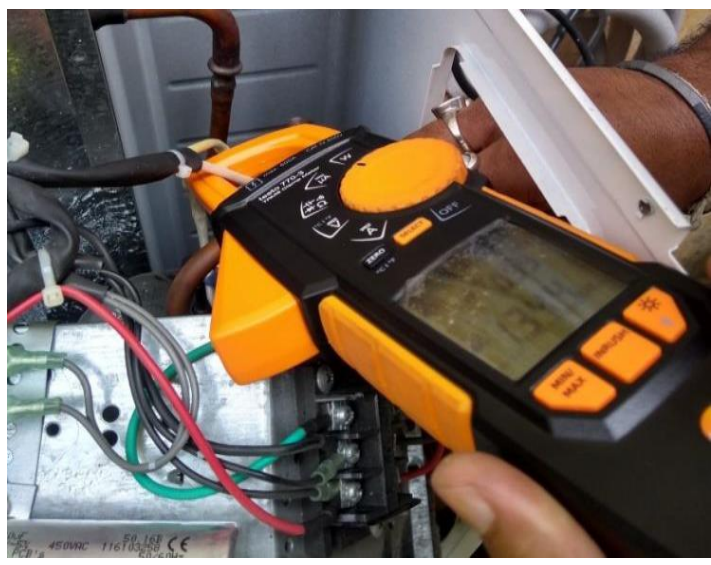

Figure3. Clamp meter

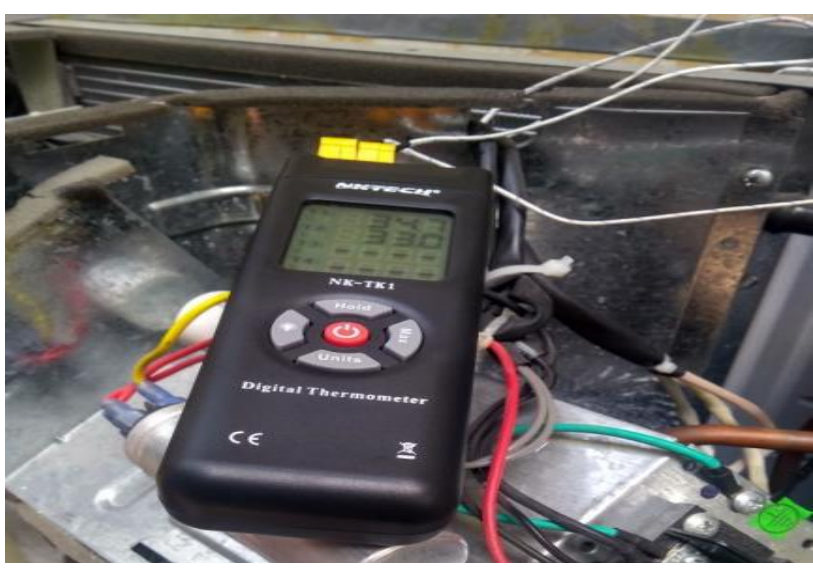

Figure4. Thermocouple

\section{III.RESULT AND DISCUSSION}

The refrigerant used in the AC is Refrigerant 22 (Monochlorodifluoromethane).

In order to calculate the total energy consumed by the Air Conditioning System at different thermal conditions it is required to calculate power, running time and stopping (Idle) time of the compressor and other electrical parameters like current, voltage etc, at those different thermal conditions (both ambient and thermal). In order to estimate this, two cases of experiments were considered. 


\section{International Advanced Research Journal in Science, Engineering and Technology}

Vol. 6, Issue 2, February 2019

Case (A): Keeping the Ambient Temperature constant and having a varying Thermostat Temperature.

From the various experiments performed, only one pair of data was considered in this paper satisfying case (A) for proper energy performance analysis.

Ambient Temperature (constant) $=32^{0} \mathrm{C}$

(a) Thermostat Temperature (varying) $=18^{0} \mathrm{C}$

(b) Thermostat Temperature (varying) $=22^{0} \mathrm{C}$

(c)Thermostat Temperature (varying) $=24^{0} \mathrm{C}$

Now for condition (a), the energy consumption obtained for duration of one hour is as shown in Table1 and the graphs were plotted to represent power and energy consumption versus time in Figure. 5 and 6.

Table 1: Power Consumption at $18^{0} \mathrm{C}$ thermostat temperature (at constant ambient temperature $=32^{0} \mathrm{C}$ )

\begin{tabular}{|c|c|c|c|c|c|c|c|c|}
\hline $\begin{array}{l}\text { Compressor/Fan } \\
\text { Condition }\end{array}$ & $\begin{array}{l}\text { Time } \\
\text { (in } \\
\mathrm{PM})=\mathrm{t}\end{array}$ & $\begin{array}{l}\text { Power(in } \\
\mathrm{kW})=\mathrm{P}\end{array}$ & $\begin{array}{l}\text { Current(in } \\
\text { Amp) }=\mathrm{I}\end{array}$ & $\begin{array}{l}\text { Power } \\
\text { Factor=p.f }\end{array}$ & $\begin{array}{l}\text { Voltage } \\
\text { (in } \\
\text { volts) }=\mathrm{V}\end{array}$ & $\begin{array}{l}\text { Run } \\
\text { Time(in } \\
\text { min) }=\mathrm{t}_{\mathrm{r}}\end{array}$ & $\begin{array}{l}\text { Idle } \\
\text { Time(in } \\
\min )=t_{s}\end{array}$ & $\begin{array}{l}\text { Energy } \\
\text { consumed(in } \\
\mathrm{kWh})=\mathrm{E}\end{array}$ \\
\hline Running & 01:08 & 1.587 & 4.5 & 0.98 & 360 & & & \multirow[b]{2}{*}{0.8199} \\
\hline Idle & $01: 39$ & 0 & 0.2 & 0.71 & 0.022 & 31 & & \\
\hline Running & $01: 43$ & 1.57 & 4.4 & 0.98 & 364 & & 4 & \multirow[b]{2}{*}{0.1832} \\
\hline Idle & $01: 50$ & 0 & 0.2 & 0.56 & 0.016 & 7 & & \\
\hline Running & $01: 53$ & 1.54 & 4.5 & 0.98 & 350 & & 3 & \multirow[b]{2}{*}{0.1540} \\
\hline Idle & 01:59 & 0 & 0.2 & 0.54 & 0.015 & 6 & & \\
\hline Running & $02: 02$ & 1.516 & 4.6 & 0.98 & 333 & & 3 & \multirow[b]{2}{*}{0.1516} \\
\hline Idle & 02:08 & 0 & 0.2 & 0.51 & 0.013 & 6 & & \\
\hline
\end{tabular}

Here,

Total running time of the compressor $=\mathrm{t}_{\mathrm{r} 1}=31+7+6+6=50 \mathrm{~min}$

Total stopping time of the compressor $=\mathrm{t}_{\mathrm{s} 1}=4+3+3=10 \mathrm{~min}$

Total energy consumed (in one hour) $=\mathrm{E}_{1=} 0.8199+0.1832+0.1540+0.1516=1.3087 \mathrm{~kW}$

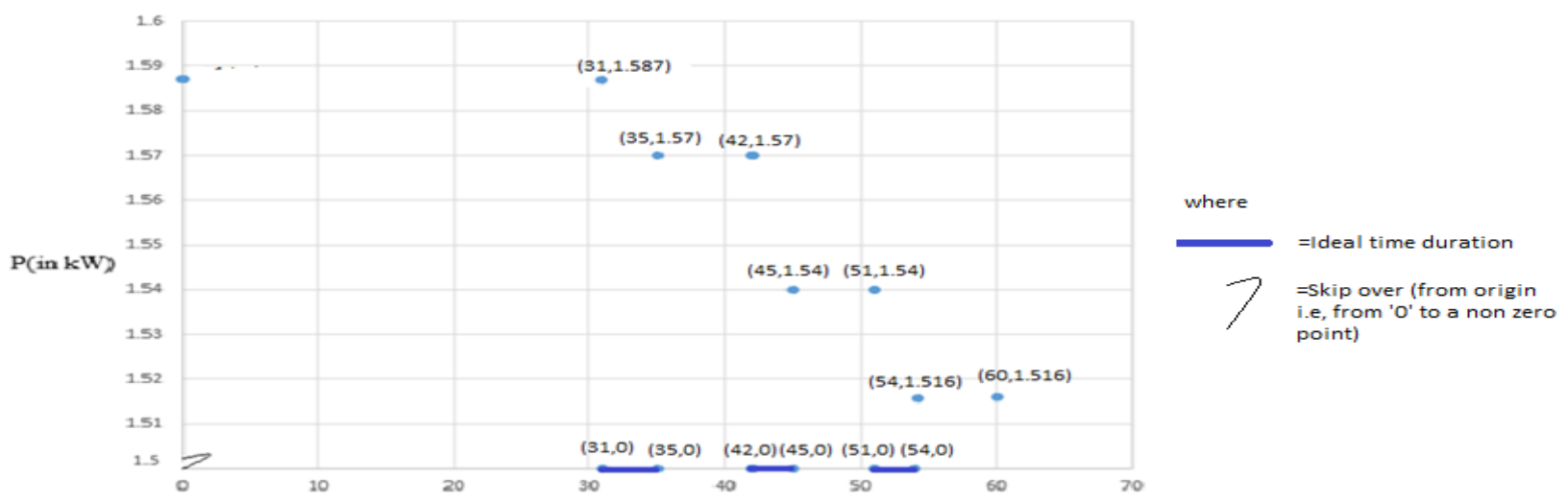

Time (in min)

Fig 5: Power Vs Time Graph for $32^{0} \mathrm{C}$ Ambient temperature and $18^{0} \mathrm{C}$ thermostat temperature.

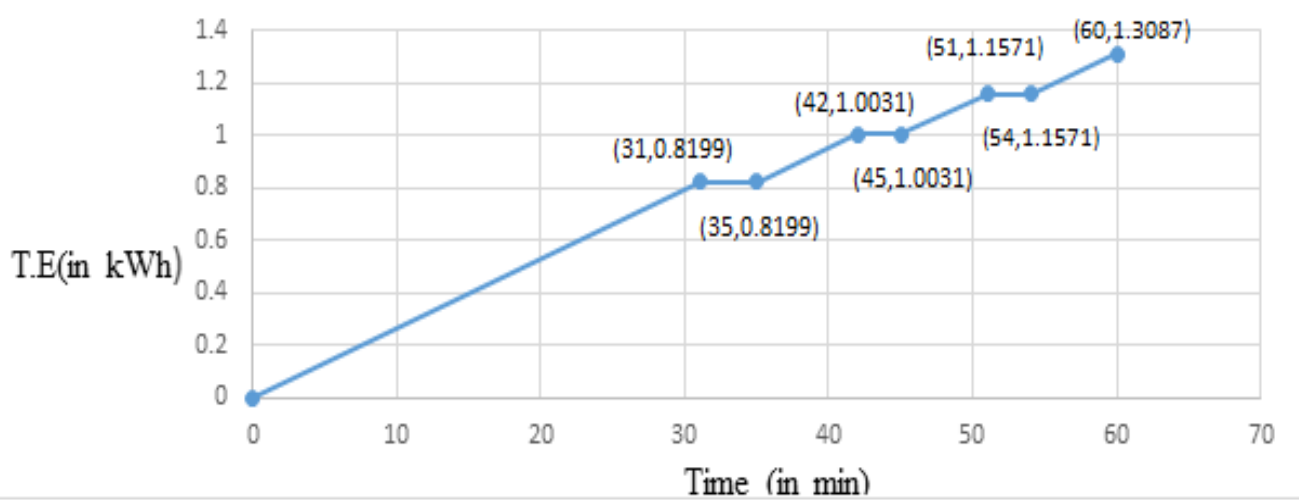

Fig 6: Total Energy Vs Time Graph for $32^{\circ} \mathrm{C}$ ambient temperature and $18^{0} \mathrm{C}$ thermostat temperature. 


\section{International Advanced Research Journal in Science, Engineering and Technology}

Vol. 6, Issue 2, February 2019

As in above, for condition (b) the power consumed by the air conditioner for duration of one hour is shown in Table. 2 and the graphs are plotted as shown in Figure. 7 and 8.

Table 2: Power Consumption at $22^{0} \mathrm{C}$ thermostat temperature (at constant ambient temperature $=32^{0} \mathrm{C}$ )

\begin{tabular}{|c|c|c|c|c|c|c|c|c|}
\hline $\begin{array}{l}\text { Compressor } \\
\text { Condition }\end{array}$ & $\begin{array}{l}\text { Time } \\
(\text { in } \\
\text { PM)=t }\end{array}$ & $\begin{array}{l}\text { Power(in } \\
\mathrm{kW})=\mathrm{P}\end{array}$ & $\begin{array}{l}\text { Current(in } \\
\text { Amp)=I }\end{array}$ & $\begin{array}{l}\text { Power } \\
\text { Factor=p.f }\end{array}$ & $\begin{array}{l}\text { Voltage } \\
\text { (in } \\
\text { volts) }=\mathrm{V}\end{array}$ & $\begin{array}{l}\text { Run } \\
\text { Time(in } \\
\min )=t_{r}\end{array}$ & $\begin{array}{l}\text { Idle } \\
\text { Time(in } \\
\text { min) }=t_{\mathrm{s}}\end{array}$ & $\begin{array}{l}\text { Energy } \\
\text { consumed(in } \\
\mathrm{kWh})=\mathrm{E}\end{array}$ \\
\hline Running & $01: 20$ & 1.54 & 4.3 & 0.98 & 365 & & & \multirow[b]{2}{*}{0.5133} \\
\hline Idle & $01: 40$ & 0 & 0.2 & 0.71 & 0.022 & 20 & & \\
\hline Running & $01: 45$ & 1.529 & 4.6 & 0.98 & 340 & & 5 & \multirow[b]{2}{*}{0.2294} \\
\hline Idle & $01: 54$ & 0 & 0.2 & 0.56 & 0.016 & 9 & & \\
\hline Running & 02:00 & 1.521 & 4.7 & 0.98 & 333.3 & & 6 & \multirow[b]{2}{*}{0.1775} \\
\hline Idle & 02:07 & 0 & 0.2 & 0.54 & 0.015 & 7 & & \\
\hline Running & $02: 13$ & 1.517 & 4.8 & 0.98 & 322 & & 6 & \multirow[b]{2}{*}{0.1264} \\
\hline Idle & $02: 18$ & 0 & 0.2 & 0.51 & 0.013 & 5 & & \\
\hline Idle & $02: 20$ & 0 & 0.2 & 0.51 & 0.013 & & 2 & 0 \\
\hline
\end{tabular}

Here,

Total running time of the compressor $=\mathrm{t}_{\mathrm{r} 2}=20+9+7+5=41 \mathrm{~min}$

Total stopping time of the compressor $=\mathrm{t}_{\mathrm{s} 2}=5+6+6+2=19$ min

Total energy consumed (in one hour) $=\mathrm{E}_{2}=0.5133+0.2294+0.1775+0.1264=1.0466 \mathrm{kWh}$

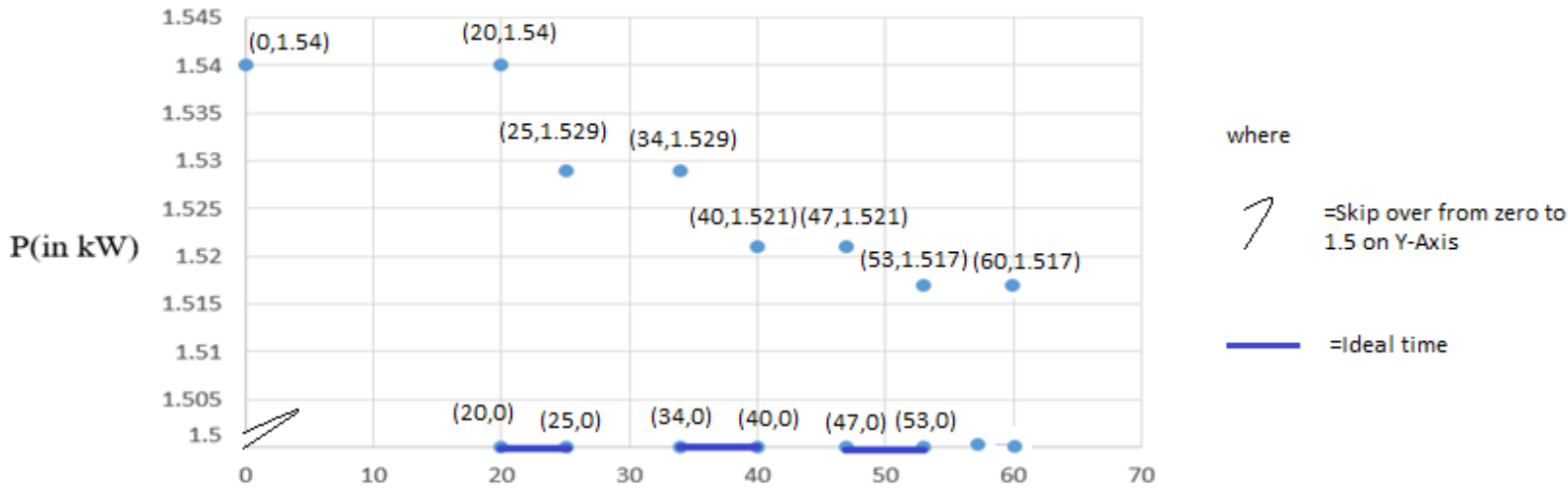

Time(in min)

Fig 7: Power Vs Time Graph for $32^{0} \mathrm{C}$ ambient temperature and $22^{0} \mathrm{C}$ thermostat temperature.

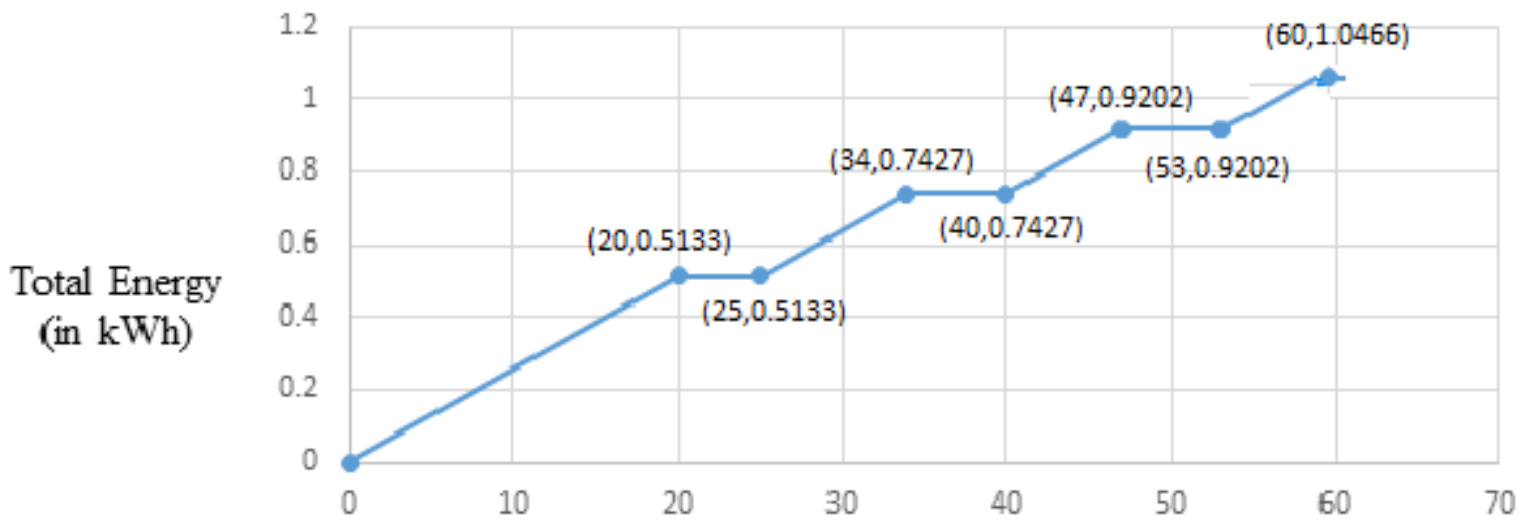

Time(in $\min$ )

Fig 8: Total Energy Vs Time Graph for $32^{\circ} \mathrm{C}$ ambient temperature and $22^{0} \mathrm{C}$ thermostat temperature. 


\section{International Advanced Research Journal in Science, Engineering and Technology}

Vol. 6, Issue 2, February 2019

Now for condition (c), the power consumed by air conditioner for duration of one hour is shown in Table 5 and the graphical presentation is expressed in Figure.9 and 10.

Table 5: Power Consumption at $24^{0} \mathrm{C}$ thermostat temperature (and at constant ambient temperature $=32^{0} \mathrm{C}$ )

\begin{tabular}{|c|c|c|c|c|c|c|c|c|}
\hline $\begin{array}{l}\text { Compressor } \\
\text { Condition }\end{array}$ & $\begin{array}{l}\text { Time } \\
\text { (in } \\
\mathrm{PM})=\mathrm{t}\end{array}$ & $\begin{array}{l}\text { Power(in } \\
\mathrm{kW})=\mathrm{P}\end{array}$ & $\begin{array}{l}\text { Current(in } \\
\text { Amp)=I }\end{array}$ & $\begin{array}{l}\text { Power } \\
\text { Factor=p.f }\end{array}$ & $\begin{array}{l}\text { Voltage } \\
\text { (in } \\
\text { volts) }=\mathrm{V}\end{array}$ & $\begin{array}{l}\text { Run } \\
\text { Time(in } \\
\text { min) }=t_{r}\end{array}$ & $\begin{array}{l}\text { Idle } \\
\text { Time(in } \\
\text { min) }=t_{s}\end{array}$ & $\begin{array}{l}\text { Energy } \\
\text { consumed(in } \\
\mathrm{kWh})=\mathrm{E}\end{array}$ \\
\hline Running & $01: 32$ & 1.35 & 4.3 & 0.98 & 322.3 & & & \multirow[b]{2}{*}{0.4275} \\
\hline Idle & $01: 51$ & 0 & 0.2 & 0.71 & 0.022 & 19 & & \\
\hline Running & $01: 56$ & 1.348 & 4.6 & 0.98 & 300 & & 5 & \multirow[b]{2}{*}{0.1797} \\
\hline Idle & 02:04 & 0 & 0.2 & 0.56 & 0.016 & 8 & & \\
\hline Running & $02: 10$ & 1.319 & 4.5 & 0.98 & 303.2 & & 6 & \multirow[b]{2}{*}{0.1319} \\
\hline Idle & $02: 16$ & 0 & 0.2 & 0.54 & 0.015 & 6 & & \\
\hline Running & $02: 22$ & 1.306 & 4.7 & 0.98 & 290.5 & & 6 & \multirow[b]{3}{*}{0.1088} \\
\hline Idle & $02: 27$ & 0 & 0.2 & 0.51 & 0.013 & 5 & & \\
\hline Idle & $02: 32$ & 0 & 0.2 & 0.51 & 0.013 & & 5 & \\
\hline
\end{tabular}

Here,

Total running time of the compressor $=\mathrm{t}_{\mathrm{r} 3}=19+8+6+5=38 \mathrm{~min}$

Total stopping time of the compressor $=\mathrm{t}_{\mathrm{s} 3}=5+6+6+5=22 \mathrm{~min}$

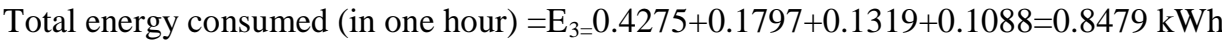

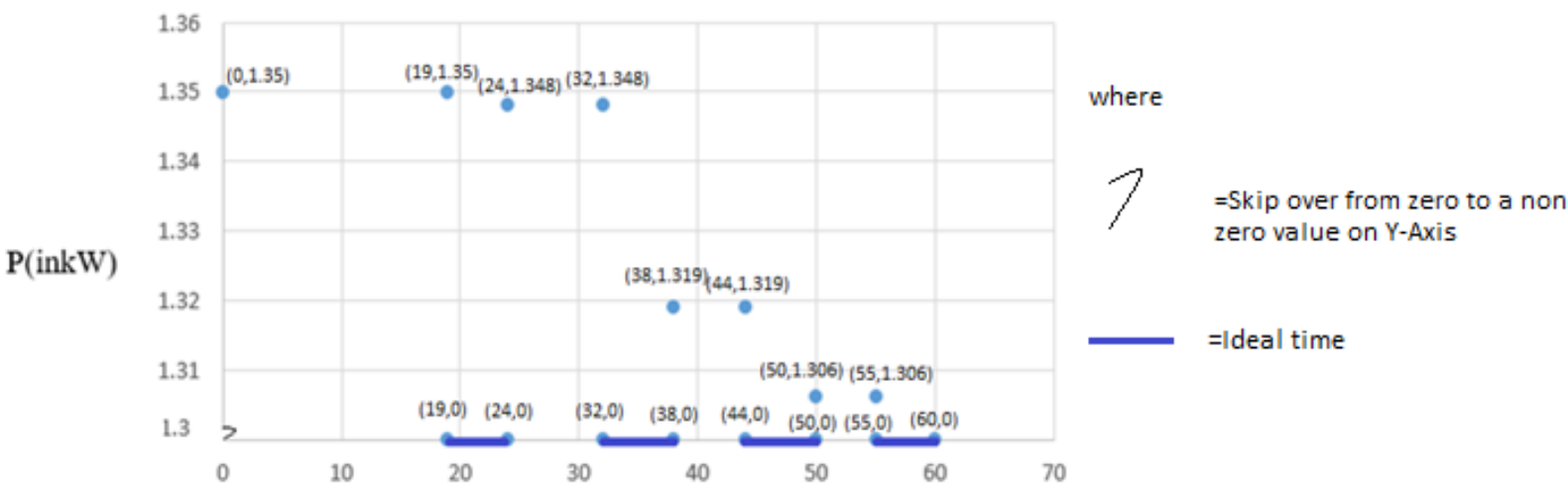

Time(in min)

Fig 9: Power Vs. Time Graph for $32^{\circ} \mathrm{C}$ ambient temperature and $24^{0} \mathrm{C}$ thermostat temperature.

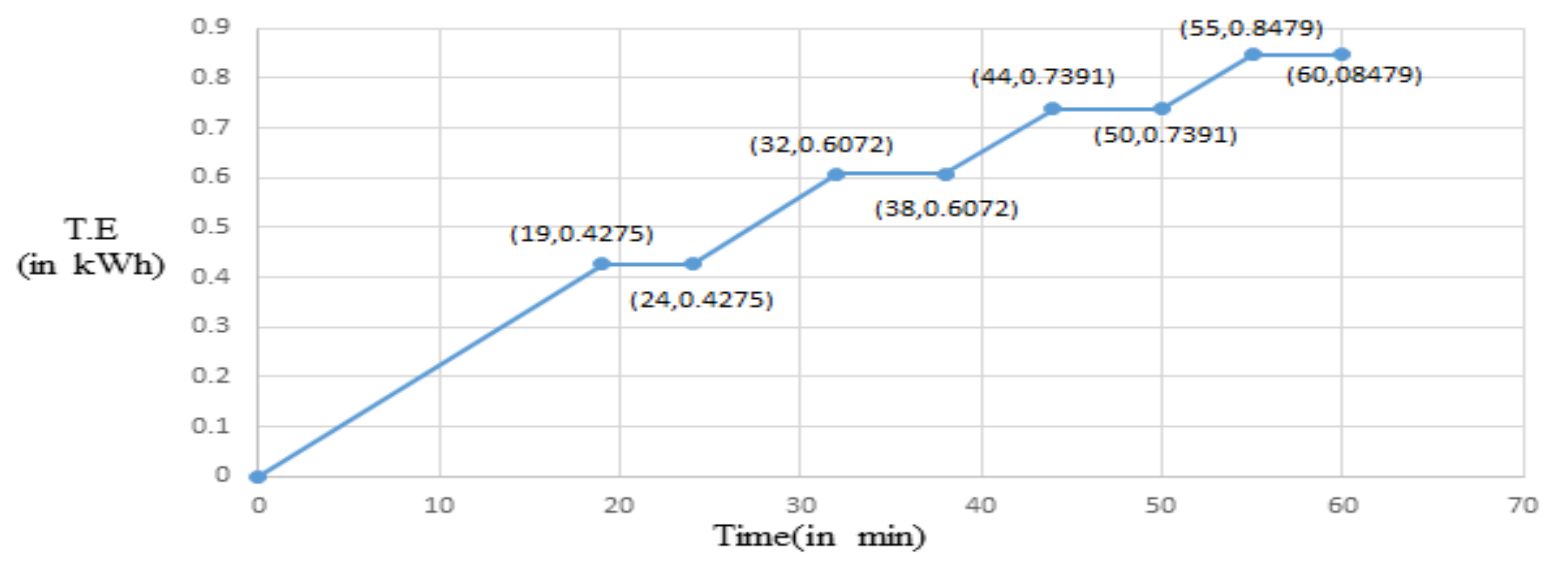

Fig10. Total Energy Vs Time Graph for $32^{0} \mathrm{C}$ ambient temperature and $24{ }^{0} \mathrm{C}$ thermostat temperature. 


\section{International Advanced Research Journal in Science, Engineering and Technology}

Vol. 6, Issue 2, February 2019

Comparing the curves of Case (A) having a constant Ambient Temperature of $32^{\circ} \mathrm{C}$, it is found that the total running time of the compressor was more when the thermostat temperature was at $22^{\circ} \mathrm{C}$ than the total running time of the compressor when the thermostat temperature was at $24^{\circ} \mathrm{C}$ i.e. $\left(\mathrm{t}_{\mathrm{r} 1}>\mathrm{t}_{\mathrm{r} 2}>\mathrm{t}_{\mathrm{r} 3}\right)$. Therefore the total Idle time (or the stopping time) of the compressor was more when the thermostat temperature was at $24^{\circ} \mathrm{C}$ than the total running time of the compressor when the thermostat temperature was at $22^{\circ} \mathrm{C}$ i.e. $\left(t_{\mathrm{s} 3}>\mathrm{t}_{\mathrm{s} 2}>\mathrm{t}_{\mathrm{s} 1}\right)$. The total energy consumed is more when the thermostat temperature is at $22^{\circ} \mathrm{C}$ than the total energy consumed when the thermostat temperature is at $24^{\circ} \mathrm{C}$ i.e. $\left(\mathrm{E}_{1}>\mathrm{E}_{2}>\mathrm{E}_{3}\right)$.

Case (B): Keeping the Thermostat Temperature constant and having a varying ambient temperature. From the various experiments performed, only one pair of data is considered to satisf case (B) for proper energy performance analysis.

Thermostat Temperature (constant) $=19^{\circ} \mathrm{C}$

(a) Ambient Temperature (varying) $=21^{\circ} \mathrm{C}$

(b) Ambient Temperature (varying) $=24^{\circ} \mathrm{C}$

(c) Ambient Temperature (varying) $=28^{\circ} \mathrm{C}$

For condition (a), the data has been collected for power consumption of air conditioner during one hour which has been shown in Table 6 with graphical presentation in Figure 11 and 12.

Table 6: Power Consumption at $21^{\circ} \mathrm{C}$ Ambient Temperature (and at constant Thermostat Temperature $=19^{\circ} \mathrm{C}$ )

\begin{tabular}{|c|c|c|c|c|c|c|c|c|}
\hline $\begin{array}{l}\text { Compressor } \\
\text { Condition }\end{array}$ & $\begin{array}{l}\text { Time } \\
\text { (in } \\
\mathrm{PM})=\mathrm{t}\end{array}$ & $\begin{array}{l}\text { Power(in } \\
k W)=P\end{array}$ & $\begin{array}{l}\text { Current(in } \\
\text { Amp)=I }\end{array}$ & $\begin{array}{l}\text { Power } \\
\text { Factor=p.f }\end{array}$ & $\begin{array}{l}\text { Voltage } \\
\text { (in } \\
\text { volts)=V }\end{array}$ & $\begin{array}{l}\text { Run } \\
\text { Time(in } \\
\text { min) }=t_{r}\end{array}$ & $\begin{array}{l}\text { Idle } \\
\text { Time(in } \\
\text { min) }=\mathrm{t}_{\mathrm{s}}\end{array}$ & $\begin{array}{l}\text { Energy } \\
\text { consumed(in } \\
\mathrm{kWh})=\mathrm{E}\end{array}$ \\
\hline Running & $01: 26$ & 1.354 & 3.7 & 0.94 & 366 & & & \multirow[b]{2}{*}{0.0226} \\
\hline Idle & $01: 27$ & 0 & 0.2 & 0.71 & 0.02 & 1 & & \\
\hline Running & $01: 30$ & 1.08 & 3.4 & 0.99 & 301 & & 3 & \multirow[b]{2}{*}{0.108} \\
\hline Idle & $01: 36$ & 0 & 0.2 & 0.7 & 0.021 & 6 & & \\
\hline Running & 01:39 & 1.2 & 3.5 & 0.96 & 358 & & 3 & \multirow[b]{2}{*}{0.1} \\
\hline Idle & $01: 44$ & 0 & 0.2 & 0.69 & 0.021 & 5 & & \\
\hline Running & $01: 48$ & 1.22 & 3.4 & 0.96 & 350 & & 4 & \multirow[t]{2}{*}{0.0813} \\
\hline Idle & $01: 52$ & 0 & 0.2 & 0.71 & 0.021 & 4 & & \\
\hline Running & 01:58 & 1.21 & 3.5 & 0.98 & 352 & & 6 & \multirow[t]{2}{*}{0.0806} \\
\hline Idle & 02:02 & 0 & 0.2 & 0.74 & 0.023 & 4 & & \\
\hline Running & $02: 10$ & 1.3 & 3.4 & 0.97 & 360 & & 8 & \multirow[t]{2}{*}{0.065} \\
\hline Idle & $02: 13$ & 0 & 0.2 & 0.70 & 0.02 & 3 & & \\
\hline Running & $02: 21$ & 1.33 & 3.4 & 0.98 & 363.1 & & 8 & \multirow[t]{2}{*}{0.1108} \\
\hline Idle & $02: 26$ & 0 & 0.2 & 0.69 & 0.021 & 5 & & \\
\hline
\end{tabular}

Here,

Total running time of the compressor $=\mathrm{t}_{\mathrm{r} 4}=1+6+5+4+4+3+5=28 \mathrm{~min}$

Total stopping time of the compressor $=\mathrm{t}_{\mathrm{s} 4}=3+3+4+6+8+8=32 \mathrm{~min}$

Total energy consumed (in one hour) $=\mathrm{E}_{4}=0.0226+0.108+0.1+0.0813+0.0806+0.065+0.1108=0.5683 \mathrm{kWh}$

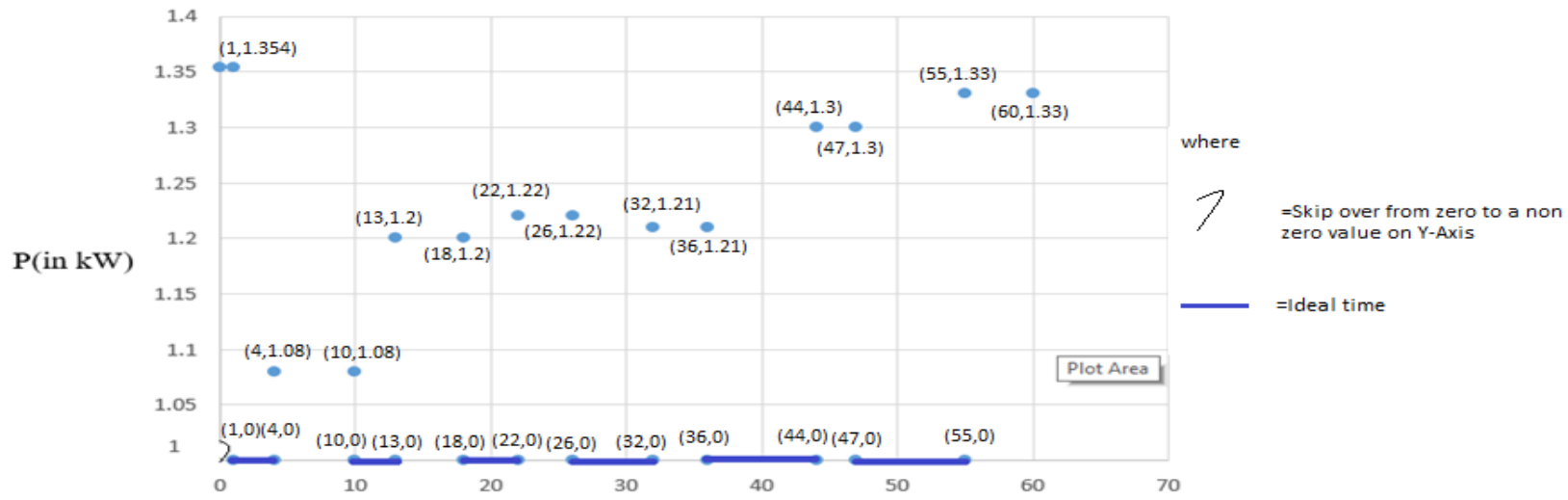

Time(in min)

Fig11: Power Vs Time Graph for $21{ }^{\circ} \mathrm{C}$ ambient temperature and $19^{\circ} \mathrm{C}$ thermostat temperature. 


\section{International Advanced Research Journal in Science, Engineering and Technology}

Vol. 6, Issue 2, February 2019

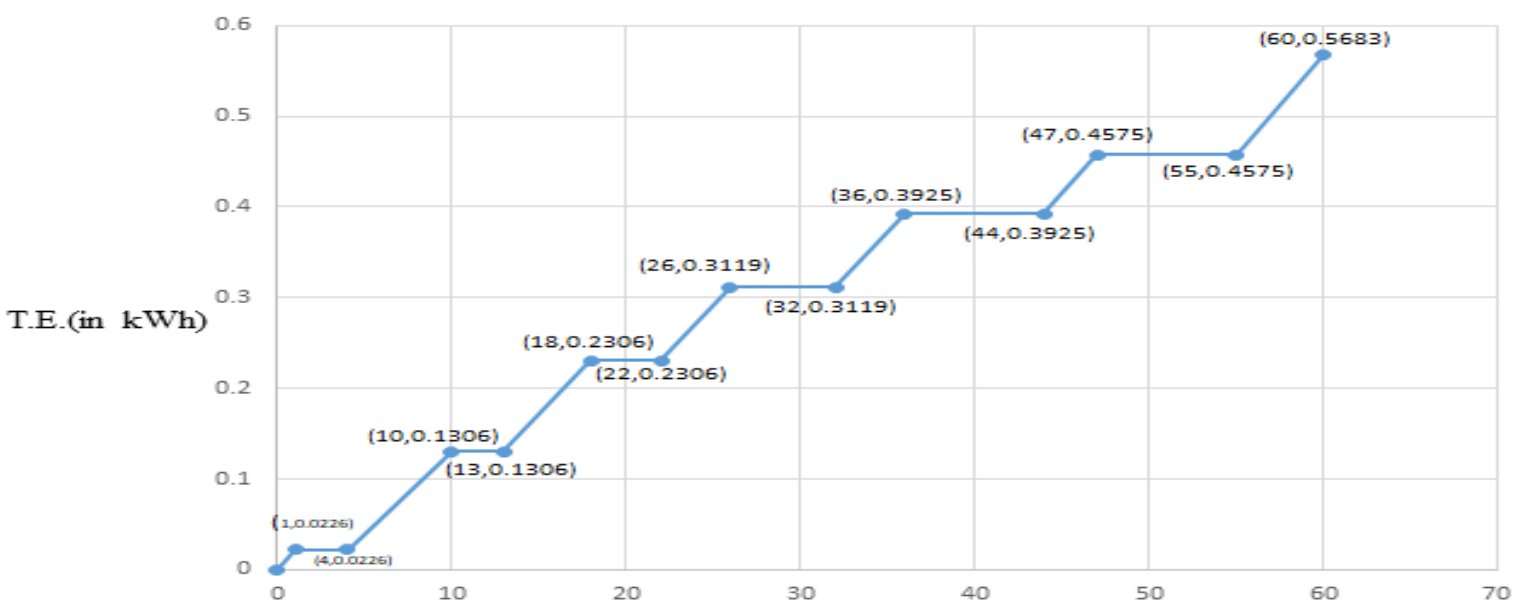

Time (in $\mathrm{min}$ )

Fig 12: Total Energy Vs Time Graph for $21^{\circ} \mathrm{C}$ ambient temperature and $19^{\circ} \mathrm{C}$ thermostat temperature.

Now, for case (b), as in the earlier case the power and energy consumption by the air conditioner is shown in Table.7 with graphical presentation in Figure 13 and 14.

Table 7: Power Consumption at $24^{\circ} \mathrm{C}$ ambient temperature (and at constant Thermostat Temperature $=19^{0} \mathrm{C}$ )

\begin{tabular}{|c|c|c|c|c|c|c|c|c|}
\hline $\begin{array}{l}\text { Compressor } \\
\text { Condition }\end{array}$ & $\begin{array}{l}\text { Time } \\
\text { (in } \\
\text { AM) }=\mathrm{t}\end{array}$ & $\begin{array}{l}\text { Power(in } \\
\mathrm{kW})=\mathrm{P}\end{array}$ & $\begin{array}{l}\text { Current(in } \\
\text { Amp)=I }\end{array}$ & $\begin{array}{l}\text { Power } \\
\text { Factor=p.f }\end{array}$ & $\begin{array}{l}\text { Voltage } \\
\text { (in } \\
\text { volts) }=\mathrm{V}\end{array}$ & $\begin{array}{l}\text { Run } \\
\text { Time(in } \\
\min )=t_{r}\end{array}$ & $\begin{array}{l}\text { Idle } \\
\text { Time(in } \\
\text { min) }=t_{s}\end{array}$ & $\begin{array}{l}\text { Energy } \\
\text { consumed(in } \\
\mathrm{kWh})=\mathrm{E}\end{array}$ \\
\hline Running & 10:01 & 1.22 & 3.8 & 0.98 & 350 & & & \multirow[b]{2}{*}{0.183} \\
\hline Idle & $10: 10$ & 0 & 0.2 & 0.73 & 0.019 & 9 & & \\
\hline Running & $10: 15$ & 1.21 & 3.77 & 0.99 & 351 & & 5 & \multirow[b]{2}{*}{0.1613} \\
\hline Idle & $10: 23$ & 0 & 0.2 & 0.69 & 0.02 & 8 & & \\
\hline Running & $10: 31$ & 1.22 & 3.8 & 0.98 & 351.2 & & 8 & \multirow[b]{2}{*}{0.1627} \\
\hline Idle & $10: 39$ & 0 & 0.2 & 0.71 & 0.022 & 8 & & \\
\hline Running & $10: 48$ & 1.19 & 3.56 & 0.98 & 351.1 & & 9 & \multirow[b]{2}{*}{0.1388} \\
\hline Idle & $10: 55$ & 0 & 0.2 & 0.79 & 0.02 & 7 & & \\
\hline Running & 11:00 & 1.23 & 3.7 & 0.98 & 353.1 & & 5 & \multirow[b]{2}{*}{0.0205} \\
\hline Running & 11:01 & 1.23 & 3.7 & 0.98 & 0.019 & 1 & & \\
\hline
\end{tabular}

Here,

Total running time of the compressor $=\mathrm{t}_{\mathrm{r} 5}=9+8+8+7+1=33 \mathrm{~min}$

Total stopping time of the compressor $=\mathrm{t}_{\mathrm{s} 5}=5+8+9+5=27 \mathrm{~min}$

Total energy consumed (in one hour) $=\mathrm{E}_{5}=0.183+0.1613+0.1627+0.1388+0.0205=0.6663 \mathrm{kWh}$

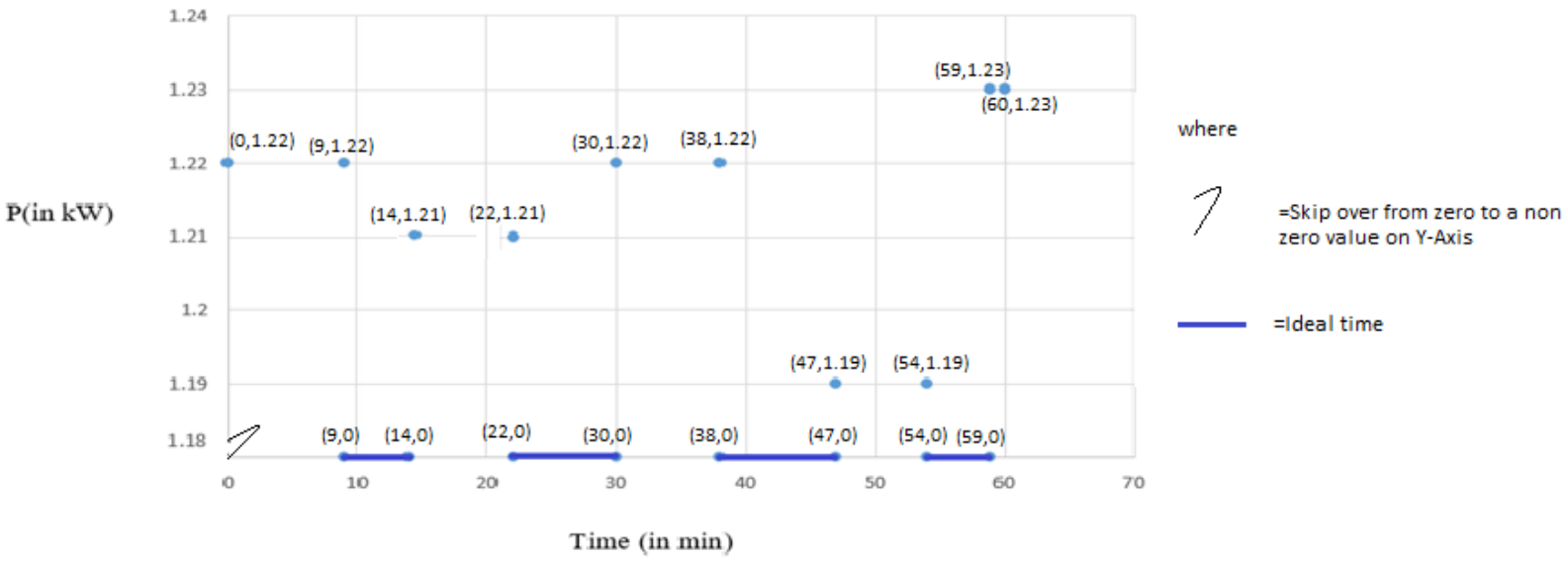

Figure13. Power Vs Time Graph for $24^{0} \mathrm{C}$ ambient temperature and $19^{\circ} \mathrm{C}$ thermostat temperature. 


\section{International Advanced Research Journal in Science, Engineering and Technology}

Vol. 6, Issue 2, February 2019

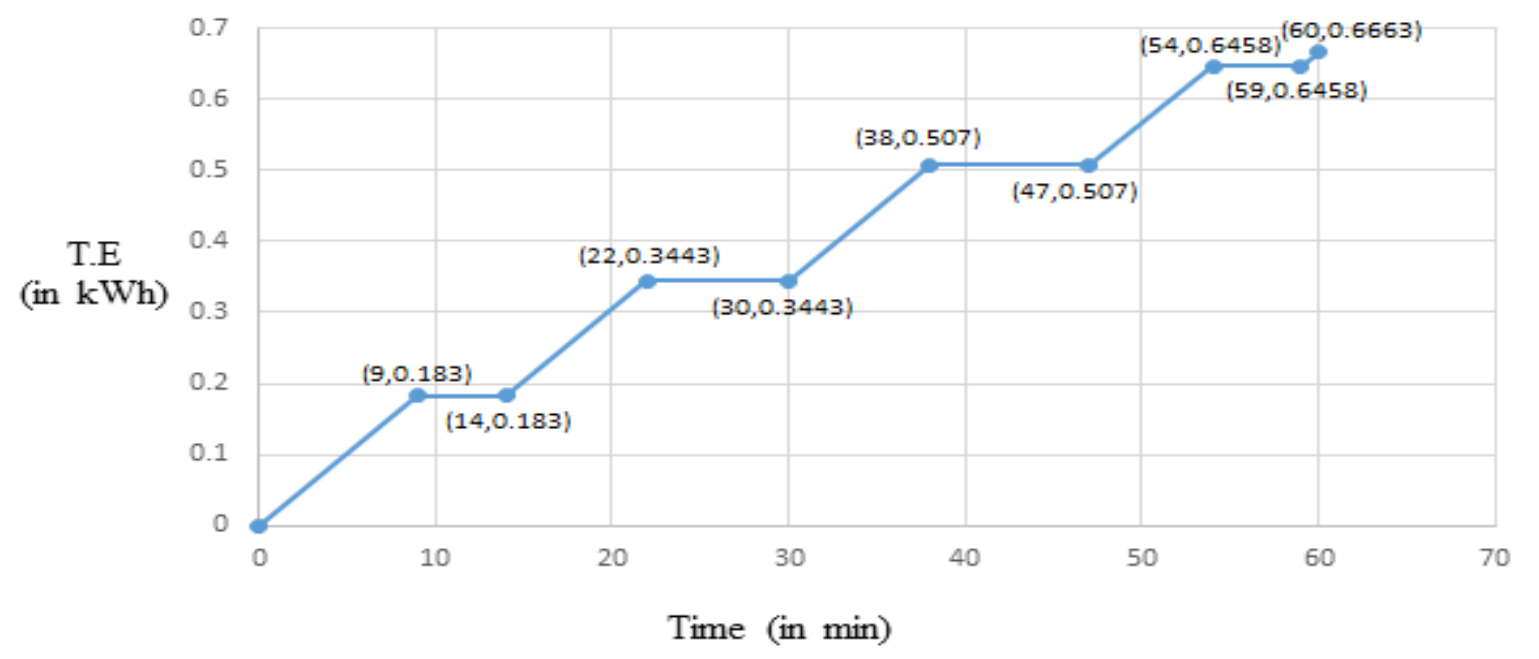

Figure14. Total Energy Vs. Time Graph for $24^{0} \mathrm{C}$ ambient temperature and $19^{0} \mathrm{C}$ thermostat temperature.

Now, for case (d), following data has been obtained in Table 8 and its graphical presentation is shown in Figure 15 and 16

Table8: Power Consumption at $28^{0} \mathrm{C}$ ambient temperature (and at constant thermostat temperature $=19^{0} \mathrm{C}$ )

\begin{tabular}{|c|c|c|c|c|c|c|c|c|}
\hline $\begin{array}{l}\text { Compressor } \\
\text { Condition }\end{array}$ & $\begin{array}{l}\text { Time } \\
\text { (in } \\
\mathrm{PM})=\mathrm{t}\end{array}$ & $\begin{array}{l}\text { Power(in } \\
\mathrm{kW})=\mathrm{P}\end{array}$ & $\begin{array}{l}\text { Current(in } \\
\text { Amp)=I }\end{array}$ & $\begin{array}{l}\text { Power } \\
\text { Factor=p.f }\end{array}$ & $\begin{array}{l}\text { Voltage } \\
\text { (in } \\
\text { volts) }=\mathrm{V}\end{array}$ & $\begin{array}{l}\text { Run } \\
\text { Time(in } \\
\text { min) }=t_{r}\end{array}$ & $\begin{array}{l}\text { Idle } \\
\text { Time(in } \\
\text { min) }=\mathrm{t}_{\mathrm{s}}\end{array}$ & $\begin{array}{l}\text { Energy } \\
\text { consumed(in } \\
\mathrm{kWh})=\mathrm{E}\end{array}$ \\
\hline Running & $12: 45$ & 1.47 & 4.6 & 0.98 & 324.3 & & & \multirow[b]{2}{*}{0.4655} \\
\hline Idle & $12: 57$ & 0 & 0.2 & 0.71 & 0.022 & 19 & & \\
\hline Running & 01:02 & 1.46 & 4.5 & 0.98 & 331 & & 3 & \multirow[b]{2}{*}{0.1947} \\
\hline Idle & $01: 12$ & 0 & 0.2 & 0.56 & 0.016 & 8 & & \\
\hline Running & $01: 19$ & 1.41 & 4.3 & 0.98 & 333.2 & & 8 & \multirow[b]{2}{*}{0.188} \\
\hline Idle & $01: 27$ & 0 & 0.2 & 0.54 & 0.015 & 8 & & \\
\hline Running & $01: 37$ & 1.46 & 4.5 & 0.98 & 330.8 & & 9 & \multirow[b]{2}{*}{0.1217} \\
\hline Idle & $01: 45$ & 0 & 0.2 & 0.51 & 0.013 & 5 & & \\
\hline
\end{tabular}

Here,

Total running time of the compressor $=\mathrm{t}_{\mathrm{r} 6}=19+8+8+5=40 \mathrm{~min}$

Total stopping time of the compressor $=\mathrm{t}_{\mathrm{s} 6}=3+8+9=20 \mathrm{~min}$

Total energy consumed (in one hour) $=\mathrm{E}_{6=} 0.4655+0.1947+0.188+0.1217=0.9699 \mathrm{kWh}$

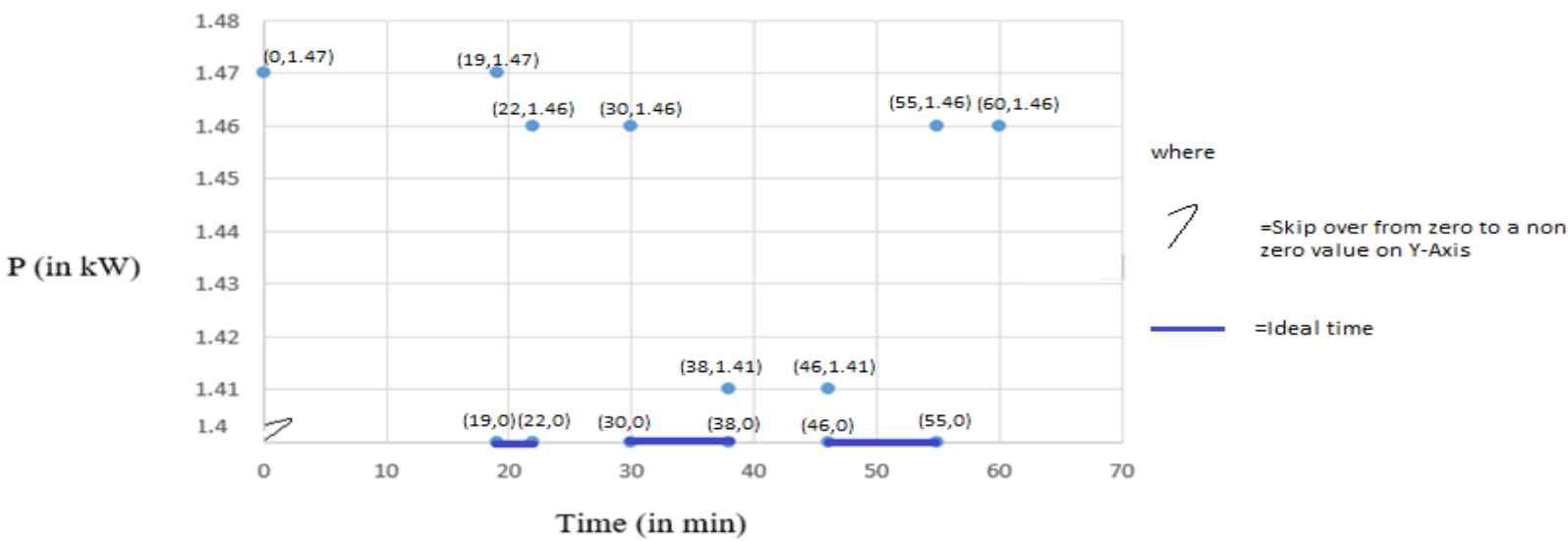

Figure15. Power Vs Time Graph for $28{ }^{0} \mathrm{C}$ ambient temperature and $19^{\circ} \mathrm{C}$ thermostat temperature. 


\section{International Advanced Research Journal in Science, Engineering and Technology}

Vol. 6, Issue 2, February 2019

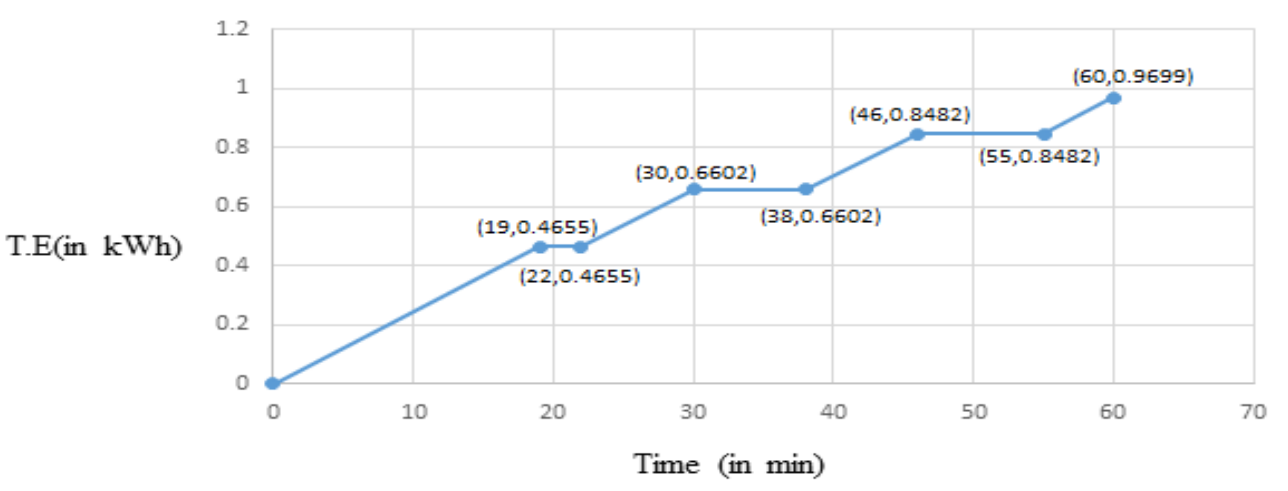

Figure 16. Total Energy Vs Time Graph for $24^{0} \mathrm{C}$ ambient temperature and $19{ }^{0} \mathrm{C}$ thermostat temperature.

Comparing the curves of Case (B) having a constant thermostat temperature of $19^{\circ} \mathrm{C}$, it is obtained that the total running time of the compressor was more when the ambient temperature was at $24^{\circ} \mathrm{C}$ than the total running time of the compressor when the ambient temperature was at $21^{\circ} \mathrm{C}$ i.e. $\left(\mathrm{t}_{\mathrm{r} 6}>\mathrm{t}_{\mathrm{r} 5}>\mathrm{t}_{\mathrm{r} 4}\right)$. Therefore the total Idle time (or the stopping time) of the compressor was more when the ambient temperature was at $21^{\circ} \mathrm{C}$ than the total running time of the compressor when the ambient temperature was at $24^{\circ} \mathrm{C}$ i.e. $\left(\mathrm{t}_{\mathrm{s} 4}>\mathrm{t}_{\mathrm{s} 5}>\mathrm{t}_{\mathrm{s} 6}\right)$. The total energy consumed is more when the ambient temperature is at $24^{\circ} \mathrm{C}$ than the total energy consumed when the ambient temperature is at $21^{\circ} \mathrm{C}$ i.e. $\left(\mathrm{E}_{6}>\mathrm{E}_{5}>\mathrm{E}_{4}\right)$. From the experiments it is seen that energy consumption of AC depends on run time of the compressor. Once the desired temperature is reached the compressor stops functioning. The compressor restarts once the thermostat detects increase in temperature. Table 9 and Table 10 show the total energy consumed varies for varying thermostat temperature and varying of ambient temperature.

Table9. Total energy consumed and percentage of energy reduction with varying thermostat temperature

\begin{tabular}{|l|l|l|l|l|l|}
\hline $\begin{array}{l}\text { At constant ambient } \\
\text { temperature }\left(32^{\circ} \mathrm{C}\right)\end{array}$ & $\begin{array}{l}\text { Total Energy } \\
\text { consumed(per kwh) }\end{array}$ & \multicolumn{2}{l|}{$\begin{array}{l}\text { Cost per unit(Rs 6.70)in } \\
\text { Guwahati }\end{array}$} & $\begin{array}{l}\text { Cost per month } \\
\text { (Rs) }\end{array}$ & $\begin{array}{l}\text { \%of energy } \\
\text { saved in } \\
\text { comparison to } \\
18^{\circ} \mathrm{C}\end{array}$ \\
\hline $\begin{array}{l}\text { Varying thermostat } \\
\text { temperature }\left({ }^{\circ} \mathrm{C}\right)\end{array}$ & & $\begin{array}{l}\text { In 1 } \\
\text { hr(Rs) }\end{array}$ & $\begin{array}{l}\text { In } 8 \text { hrs/day } \\
(\mathrm{Rs})\end{array}$ & & \\
\hline 18 & 1.3087 & 8.7682 & 70.1456 & $2104.36($ Ref $)$ & \\
\hline 22 & 1.0466 & 7.0122 & 56.0976 & 1682.92 & 25.04 \\
\hline 24 & 0.8479 & 5.6809 & 45.4474 & 1363.42 & 54.34 \\
\hline
\end{tabular}

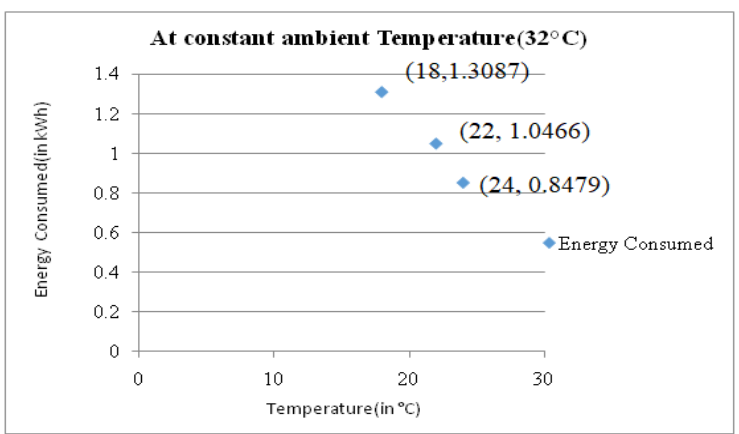

Figure17. Energy consumption vs. thermostat temp.

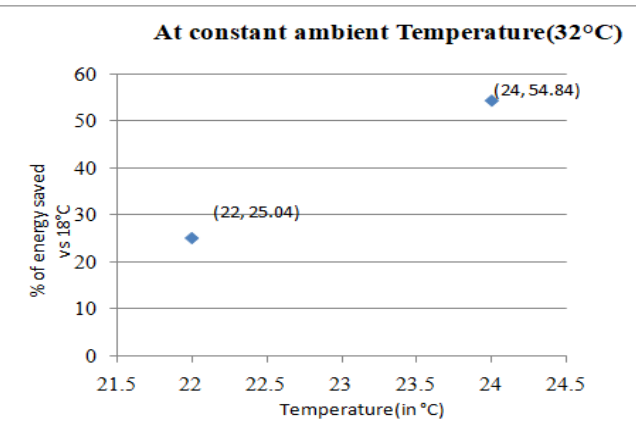

Figure18.Energy savings in higher temperature

In Figure 17 and 18 it shows that how the energy consumption of air conditioner can be reduced by controlling the thermostat temperature. Whereas in Figure 19 and 20 the plotted graph shows that energy consumption rate increases for the increasing of ambient temperature. 


\title{
International Advanced Research Journal in Science, Engineering and Technology
}

\author{
Vol. 6, Issue 2, February 2019
}

Table10. Total energy consumed and percentage of energy reduction with varying thermostat temperature

\begin{tabular}{|l|l|l|l|l|l|}
\hline $\begin{array}{l}\text { At constant } \\
\text { thermostat } \\
\text { temperature }\left(19^{\circ} \mathrm{C}\right)\end{array}$ & $\begin{array}{l}\text { Total Energy consumed } \\
\text { (per kwh) }\end{array}$ & \multicolumn{2}{l|}{$\begin{array}{l}\text { Cost per unit(Rs 6.70)in } \\
\text { Guwahati }\end{array}$} & $\begin{array}{l}\text { Cost per month } \\
\text { (Rs) }\end{array}$ & $\begin{array}{l}\text { \%of energy } \\
\text { saved in } \\
\text { comparison to } \\
28^{\circ} \mathrm{C}\end{array}$ \\
\hline $\begin{array}{l}\text { Varying ambient } \\
\text { temperature }\left({ }^{\circ} \mathrm{C}\right)\end{array}$ & & $\begin{array}{l}\text { In } 1 \\
\text { hr(Rs) }\end{array}$ & $\begin{array}{l}\text { In } 8 \text { hrs/day } \\
(\mathrm{Rs})\end{array}$ & & \\
\hline 21 & 0.5683 & 3.8076 & 30.4608 & 913.82 & 70.66 \\
\hline 24 & 0.6663 & 4.4642 & 35.7136 & 1071.40 & 45.56 \\
\hline 28 & 0.9699 & 6.4983 & 51.9866 & $1559.59(\mathrm{Ref})$ & \\
\hline
\end{tabular}

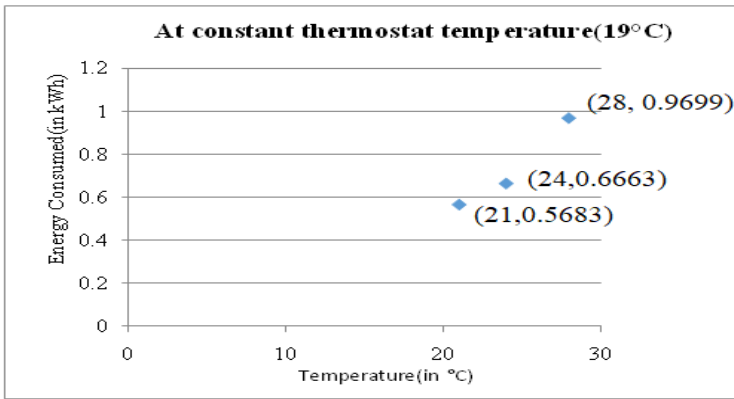

Figure19. Energy consumption vs. ambient temperature

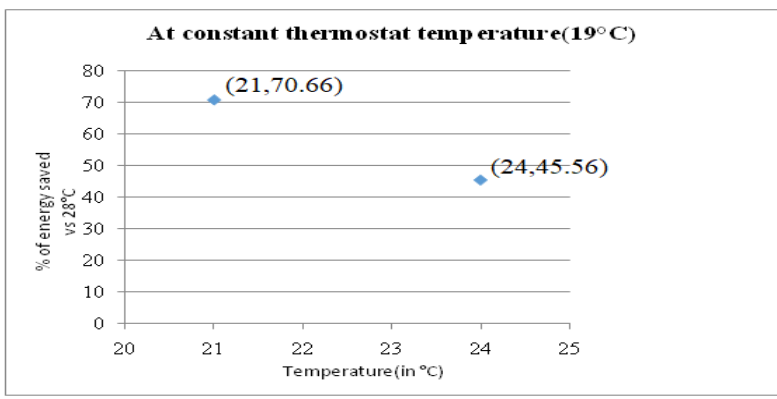

Figure20. Energy savings in lower temperature

\section{IV.CONCLUSION}

From the above results and discussion it is clear that the performance of air conditioner in terms of power consumption is not dependent only in the energy efficiency ratio (EER) of air conditioner but also hugely dependent on thermostat setting temperature and ambient temperature. Power consumed by the air conditioner can be controlled efficiently by controlling the thermostat temperature. It can be concluded that when the temperature difference between the ambient and the thermostat is more, the compressor running time is more which leads to more energy consumption .This is because when the temperature difference between the ambient and the thermostat is more, it implies that the compressor needs to run for a longer period in order to bring the temperature of the room from the ambient to the required thermostat temperature. From the experimental study it can be concluded that that at a constant ambient temperature of $32^{0} \mathrm{C}$ when the thermostat temperature set at $18^{0} \mathrm{C}, 22^{\circ} \mathrm{C}$ and $24^{0} \mathrm{C}, 21 \%$ and $35 \%$ of power can be shaved in case of $22^{0} \mathrm{C}$ and $24^{0} \mathrm{C}$ in comparison to $18^{\circ} \mathrm{C}$. This paper further indicates that at constant thermostat temperature of $19^{\circ} \mathrm{C}$ when the ambient temperature varies like $21^{\circ} \mathrm{C}, 24^{\circ} \mathrm{C}$ and $28^{\circ} \mathrm{C}, 15 \%$ and $41 \%$ power reduction occurs in case of $24^{0} \mathrm{C}$ and $21^{\circ} \mathrm{C}$ in comparison to $28^{\circ} \mathrm{C}$.

\section{REFERENCES}

[1] QUANG T N,HE Cong-rong, KNIBBS L D,DEAR R D;" Investigation on co-optimisation of indoor environmental quality and energy consumption"; Journal of Energy reports, Vol 87,2014.

[2] A Avgelis , AM Papadopoulos;"Application of multi-criteria analysis in designing HVAC systems";Journal of Energy and Buildings,Vol.5,2009.

[3] Shailendra Singh Chauhan, SPS Rajput; "Thermodynamics analysis of the evaporative vapour compression based combined air conditioning system for hot and dry climatic condition"; Journal of Building Engineering, Vol.4, 2015.

[4] I.P Knight and G N Dunn;"The energy consumption of Air Conditioning system in UK office environment"; Journal of Building Engineering, Vol 223,2002

[5] Ruey Lung Hwang and Ming Jen Chung ;"field survey on human thermal comfort reports in Air-conditioned offices in Taiwan";Journal of The Open Construction and Building Technology, Vol 75,2007.

[6] Nan Wang, Jiangfeng Zhang and Xiaohua Xia;"Energy consumption of air conditioners at different temperature set points";Journal of Energy and Buildings, Vol 456,2013.

[7] Xin Zhou, Da Yan and Xing Shi;"Comparative research on different air conditioning systems for residential buildings"; Frontiers of Architectural Research, Vol 231,2016.

[8] Brahim Mebarki, Belkacem Draoui, Boumediene Allaou and Lakhdar Rahmani;"'Impact of Air-Conditioning system on the power consumption of an electric vehicle powered by Lithium-Ion battery"; Journal of Energy band Buildings, Vol 220,2013.

[9] B.F Yu, Z.B Hu,M.Liu,H.L Yang and Y.H Liu;"Review of research on air-conditioning systems and indoor air quality control for human health, Vol 123,2007

[10] Kwesi Mensah and Jong Min Choi,"Energy Consumption and Stability Investigation of Constant Temperature and Humidity Test Chamber,"International Journal of Air-Conditioning and Refrigeration,Vol 532,2016 